\title{
Estimating Environmental Contamination and Element Deposition at an Urban Area of Central Italy
}

\author{
Stefano Loppi ${ }^{1, *(\mathbb{D})}$, Adelmo Corsini ${ }^{2}$ and Luca Paoli ${ }^{3}$ \\ 1 Department of Life Sciences, University of Siena, 53100 Siena, Italy \\ 2 via Porta San Marco 196, 51100 Pistoia, Italy \\ 3 Department of Biology, University of Pisa, 56126 Pisa, Italy \\ * Correspondence: stefano.loppi@unisi.it; Tel.: +39-0577-233740
}

Received: 25 June 2019; Accepted: 17 July 2019; Published: 23 July 2019

\begin{abstract}
Air quality monitoring in many urban areas is based on sophisticated and costly equipment to check for the respect of environmental quality standards, but capillary monitoring is often not feasible due to economic constraints. In such cases, the use of living organisms may be very useful to complement the sparse data obtained by physico-chemical measurements. In this study, the bioaccumulation of selected trace elements ( $\mathrm{Al}, \mathrm{As}, \mathrm{Cd}, \mathrm{Ce}, \mathrm{Cr}, \mathrm{Cu}, \mathrm{Fe}, \mathrm{Ni}, \mathrm{Pb}, \mathrm{S}, \mathrm{Sb}, \mathrm{Zn}$ ) in lichen samples (Evernia prunastri) transplanted for three months at an urban area of Central Italy was investigated to assess the main environmental contaminants, their sources, and the fluxes of element depositions. The results pinpointed $\mathrm{Cu}$ and $\mathrm{Sb}$ as the main contaminants and suggested a common origin for these two elements from non-exhaust sources of vehicular traffic, such as brake abrasion. Most study sites were, however, found to be subjected to low or moderate environmental contamination, and the lowest contamination corresponded to the main green areas, confirming the important protective role of urban forests against air pollution. Ranges of estimated mean annual element deposition rates in the study area were similar or lower than those reported for other urban areas.
\end{abstract}

Keywords: air pollution; air quality; bioaccumulation; biomonitoring; heavy metals

\section{Introduction}

More than $80 \%$ of the EU population lives in urban areas, and as a consequence urban air pollution affects the quality of life of most citizens [1]. Notwithstanding some improvement to complement the sparse data obtained by physico-chemical measurements, essentially induced by the implementation of EU legislation on emissions of air pollutants, key EU air quality standards for the protection of human health, especially the concentration of particulate matter (PM), are currently not being met in more than $80 \%$ of urban areas [2]. Among atmospheric components, particulate matter is peculiar, being defined on the basis of its size and not on its chemical composition. It may include a wide array of elemental and organic carbon compounds; oxides of silicon, aluminum and iron; trace metals; sulphates; nitrates; and ammonia. Coarse PM consists mainly of particles derived from the Earth's crust and are thus enriched in oxides of iron, calcium, silicon, and aluminum, while fine PM is composed primarily by sulphate, nitrate, ammonium, inorganic and organic carbon compounds, and heavy metals. According to the World Health Organization [2], long-term exposure to PM is linked to cardiovascular and lung diseases, heart attacks and arrhythmias, disorder of the central nervous and the reproductive systems, and can cause cancer. In urban areas, high levels of PM are mainly caused by emissions from road traffic, which thus will require further action for improvement.

Studies on atmospheric deposition mostly investigated remote areas to evaluate the impact of pollutants such as nitrogen and mercury on ecosystems, and deposition fluxes of air pollutants are 
rarely monitored in urban areas [3]. However, such studies are very important for the evaluation of potential impacts on human health, e.g., by the bioaccumulation of contaminants through the food chain of products from urban horticulture [4].

Nowadays, many urban areas have an air quality monitoring network to check whether the set environmental standards are met or not, but capillary monitoring is currently not feasible in all cities due to economic constraints related to the establishment and maintenance of sophisticated and costly equipment. In such cases, the use of living organisms may be very useful to complement the sparse data obtained by physico-chemical measurements.

The use of lichens for assessing atmospheric levels and deposition patterns of trace elements is well-established [5], and there is evidence that lichen biomonitoring may also be profitably used in environmental forensics [6,7]. Lichens are highly dependent on the atmosphere for nutrients and lack a waxy cuticle and stomata, typical of leaves of higher plants, allowing airborne contaminants to be absorbed over the whole thallus surface. For this reason, they can be profitably used as bioaccumulators in monitoring studies. Lichens take up elements in three ways: As particulate matter, as ions accumulated extracellularly, and as ions accumulated intracellularly [8], and it is generally accepted that elements accumulated in lichen thalli reflect bulk element deposition from the atmosphere [9].

In bioccumulation studies, the technique of lichen transplants, i.e., samples taken from an unpolluted site and transferred to the study area, has several advantages over the use of native samples: It overcomes the limit of the absence of native lichens in heavily polluted areas (and also in urban contexts), the exposure time is known, and the interpretation of the results can be based on pre-exposure (control) values [9]. Furthermore, the interpretation of lichen bioaccumulation data becomes of paramount importance in decision-making processes and environmental forensics, requiring standardized procedures that account for data uncertainty and produce clear outcomes $[6,7,10]$.

In this study, we investigated the bioaccumulation of selected trace elements in lichen samples transplanted for three months in an urban area of Central Italy and delineated, by integrating recently proposed interpretative methods $[6,10]$, the main environmental contaminants, their sources, and fluxes of element depositions in lichens converted as estimates of their average annual deposition rates.

\section{Materials and Methods}

\subsection{Study Area and Sampling Design}

The study was carried out in the urban area of Montecatini Terme $\left(43^{\circ} 53^{\prime} 00^{\prime \prime}, 10^{\circ} 46^{\prime} 21^{\prime \prime}\right.$; Tuscany, Central Italy), a small town of ca. 20,000 inhabitants, relying on tourism for its economy. Vehicular traffic and heating systems are the main local sources of air pollutants. The topography is flat, with average elevation of ca. $30 \mathrm{~m}$ a.s.l. The climate is optimal for lichen metabolism, being humid sub-Mediterranean with mean annual rainfall of $1120 \mathrm{~mm}$, mean annual temperature of $15.8^{\circ} \mathrm{C}$, and mean annual relative humidity of $65 \%$. Twenty-one sampling sites were selected according to a systematic sampling design, covering the whole urban area (Figure 1). Each sampling site was represented by a circumference with a radius of $200 \mathrm{~m}$.

\subsection{Lichen Transplants}

The fruticose (shrub-like) lichen Evernia prunastri (L.) Ach., a species widely used in biomonitoring studies (e.g., [9,11]), was collected for the transplant experiment in a remote area of Tuscany (Central Italy), far from any local source of air pollution. The trace element content of lichens from this area is known to be in line with background values [9].

Lichen thalli were transplanted at the 21 sampling sites (three per site), suspended to the branches of available trees, at about $2 \mathrm{~m}$ from ground using nylon strings, simulating natural conditions. A single lichen sample was suspended to each tree, and the minimum distance between trees was $10 \mathrm{~m}$ to 
account for possible spatial autocorrelation [12]. Samples remained exposed for three months, from 17 March to 17 June 2016.

\subsection{Chemical Analysis}

About $250 \mathrm{mg}$ of lichen material was mineralized with a mixture of $3 \mathrm{~mL}$ of $70 \% \mathrm{HNO}_{3}, 0.2 \mathrm{~mL}$ of $60 \% \mathrm{HF}$, and $0.5 \mathrm{~mL}$ of $30 \% \mathrm{H}_{2} \mathrm{O}_{2}$ in a microwave digestion system (Milestone Ethos 900 ) at $280{ }^{\circ} \mathrm{C}$ and 55 bar. The concentration of 12 selected elements ( $\mathrm{Al}, \mathrm{As}, \mathrm{Cd}, \mathrm{Ce}, \mathrm{Cr}, \mathrm{Cu}, \mathrm{Fe}, \mathrm{Ni}, \mathrm{Pb}, \mathrm{S}, \mathrm{Sb}, \mathrm{Zn}$ ) was assessed by ICP-MS (Perkin-Elmer Sciex 6100) and expressed on a dry weight basis ( $\mu \mathrm{g} / \mathrm{g} \mathrm{dw})$. These elements were selected being among the most commonly investigated in similar studies and also commonly found in urban environments. Analytical quality was checked with the Standard Reference Materials IAEA-336 "lichen", and GBW-07604 "poplar leaves" for Ni and S, missing in IAEA-336. Recoveries were in the range $92-109 \%$. Precision of analysis was estimated by the relative standard deviation of 5 replicates and was $<10 \%$ for all elements. For each station, three independent replicates were analyzed. Uncertainties of mean values were $<14 \%$.

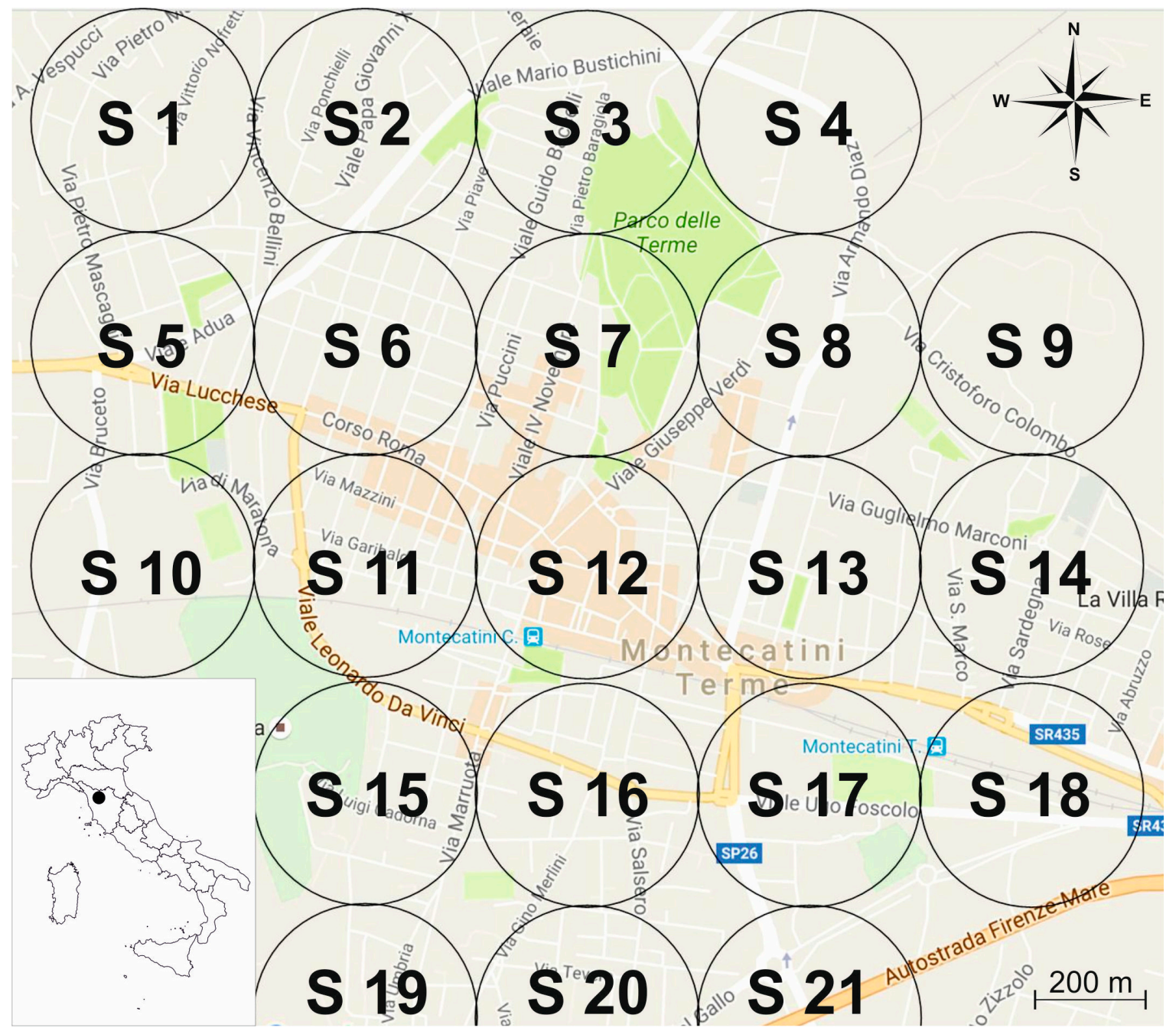

Figure 1. Map of the study area with indication of the sampling sites.

\subsection{Data Elaboration}

An integrated three-step method, suggested by Contardo et al. [6], for the identification of elements contaminating the study area followed, as listed below. 
(1) The first step consisted of the definition of an "effect detection limit" (EDL) [13], i.e., a threshold background value for each element, based on the calculation of the limit of quantification (LOQ) of pre-exposure samples [14], consisting of the mean +10 times the standard deviation, thus accounting for both the analytical noise and the noise associated with the methodology of the transplant technique. EDL values were used to quantify element bioaccumulation by the calculation of exposed/pre-exposure (control) ratios (EC ratios, as defined by Frati et al. [15]). Elements were regarded as accumulated in the study area if the EC was $>1$ in at least $50 \%$ of sites (median EC $>1$ ), thus minimizing the risk of type I errors [6];

(2) Since several studies have showed that the concentration of some elements in lichens may increase due to the accumulation of resuspended soil particles [16], in the second step, to evaluate the airborne or soilborne origin of elements, concentrations in lichens were normalized to those in soils (using $\mathrm{Al}$ as reference) by calculating enrichment factors (EFs) for each element [16] according to the formula:

$$
\mathrm{EF}=\frac{[\text { element }] /[\mathrm{Al}] \text { lichen }}{[\text { element]/[Al] soil }}
$$

Element concentrations for Italian topsoils were taken from Bini et al. [17] and Nannoni and Protano [18]. Elements with EF $>10$ in at least $50 \%$ of sites (median EF $>10$ ) were regarded as mainly of atmospheric origin [16];

(3) In the third step, to allow each sampling site to be characterized by a synthetic value, a contamination index (CI) was calculated as the geometric mean of those elements with median $\mathrm{EC}>1$ and median $\mathrm{EF}>10$. The interpretation of $\mathrm{CI}$ values was based on the scale suggested by Cecconi et al. [10] for lichens transplanted for 12 weeks.

\subsection{Estimation of Deposition Rates}

The concentrations of trace elements accumulated by lichens can be converted into estimates of heavy metal deposition rates [5,19]. To do this, a weight/area ratio of E. prunastri of $\sim 160 \mathrm{~g} / \mathrm{m}^{2}$ was calculated by cutting several thallus pieces and measuring their surface area and dry weight. Based on the known exposure time of 3 months and assuming that the final concentrations represent an equilibrium with the new environment, it was possible to convert element concentrations in lichens into estimates of average annual element deposition rates.

\section{Results}

For each investigated element, Table 1 shows threshold values for background concentrations (the so-called "effect detection limits"-EDL), mean values of exposed samples, median values of exposed to control (EC) ratios, and of enrichment factors (EFs). In summary, EC $>1$ emerged for $\mathrm{Cr}$, $\mathrm{Cu}$, and $\mathrm{Sb}, \mathrm{EFs}>10$ were found for $\mathrm{Cd}, \mathrm{Cu}, \mathrm{S}, \mathrm{Sb}$, and $\mathrm{Zn}$. Based on these findings, a contamination index $(\mathrm{CI})$ was calculated by the geometric mean of $\mathrm{EC}$ ratios of $\mathrm{Cu}$ and $\mathrm{Sb}$ and is represented in Table 2. According to the interpretative scale suggested by Cecconi et al. [10], most of the study sites $(86 \%)$ were concerned with low or moderate environmental contamination. Copper was accumulated in lichen transplants in $76 \%$ of the sampling sites, with values in the range $1-1.8$, indicating a low bioaccumulation, while $\mathrm{Sb}$ was accumulated at all sites, with $43 \%$ of values indicating high or very high accumulation (Table 2). These results clearly pinpoint $\mathrm{Sb}$ as the main contaminant in the study area. Notably, the lowest contaminations were found in proximity of the main urban forested park and other green areas of the town (Table 2). 
Table 1. Effect detection limit (EDL, $\mu \mathrm{g} / \mathrm{g} \mathrm{dw}$ ) of unexposed (control) samples, mean $( \pm \mathrm{SD}) \mathrm{values}(\mu \mathrm{g} / \mathrm{g}$ $\mathrm{dw}$ ) of exposed samples (EXP), median exposed-to-control ratios (EC), median enrichment factors (EFs).

\begin{tabular}{ccccc}
\hline Element & EDL & EXP & EC & EF \\
\hline $\mathrm{Al}$ & 1717 & $570 \pm 125$ & 0.33 & ---- \\
\hline $\mathrm{As}$ & 0.32 & $0.24 \pm 0.05$ & 0.72 & 0.8 \\
\hline $\mathrm{Cd}$ & 0.17 & $0.09 \pm 0.01$ & 0.53 & 13.5 \\
\hline $\mathrm{Ce}$ & 3.6 & $1.2 \pm 0.2$ & 0.33 & 1.7 \\
\hline $\mathrm{Cr}$ & 1.6 & $1.8 \pm 0.3$ & 1.10 & 1.6 \\
\hline $\mathrm{Cu}$ & 7.9 & $10.1 \pm 2.4$ & 1.17 & 21.6 \\
\hline $\mathrm{Fe}$ & 678 & $495 \pm 81$ & 0.72 & 1.3 \\
\hline $\mathrm{Ni}$ & 6.2 & $2.7 \pm 1.2$ & 0.36 & 4.6 \\
\hline $\mathrm{Pb}$ & 2.7 & $2.4 \pm 0.2$ & 0.87 & 7.2 \\
\hline $\mathrm{S}$ & 1145 & $694 \pm 90$ & 0.60 & 82.3 \\
\hline $\mathrm{Sb}$ & 0.10 & $0.31 \pm 0.17$ & 2.59 & 17.3 \\
\hline $\mathrm{Zn}$ & 80 & $36 \pm 7$ & 0.44 & 31.8 \\
\hline
\end{tabular}

Table 2. Exposed-to-control (EC) ratios of $\mathrm{Cu}$ and $\mathrm{Sb}$, and contamination index (CI) for each sampling site (S), as well as interpretation (Int) of CI values according to the scale of Cecconi et al. [10]: $1=$ absence of contamination, 2 = low contamination, 3 = moderate contamination, $4=$ high contamination.

\begin{tabular}{ccccc}
\hline Site & Cu & Sb & CI & Int \\
\hline S 1 & 1.28 & 1.14 & 1.21 & 2 \\
S 2 & 1.13 & 1.31 & 1.22 & 2 \\
S 3 & 1.15 & 3.01 & 1.86 & 3 \\
S 4 & 1.81 & 5.81 & 3.24 & 4 \\
S 5 & 1.53 & 2.92 & 2.11 & 3 \\
S 6 & 1.02 & 2.11 & 1.47 & 2 \\
S 7 & 0.79 & 1.18 & 0.96 & 1 \\
S 8 & 1.50 & 5.15 & 2.78 & 3 \\
S 9 & 1.63 & 5.36 & 2.96 & 3 \\
S 10 & 0.88 & 1.56 & 1.18 & 2 \\
S 11 & 1.12 & 2.54 & 1.69 & 2 \\
S 12 & 1.35 & 3.06 & 2.03 & 3 \\
S 13 & 1.60 & 1.55 & 1.58 & 2 \\
S 14 & 1.55 & 4.96 & 2.77 & 3 \\
S 15 & 1.02 & 1.93 & 1.40 & 2 \\
S 16 & 1.79 & 6.56 & 3.43 & 4 \\
S 17 & 1.35 & 4.01 & 2.33 & 3 \\
S 18 & 1.15 & 2.36 & 1.64 & 2 \\
S 19 & 0.79 & 1.66 & 1.15 & 2 \\
S 20 & 1.17 & 2.86 & 1.83 & 3 \\
S 21 & 1.13 & 2.59 & 1.71 & 2 \\
\hline
\end{tabular}

Table 3 summarizes the ranges ( $\min -\max$ ) of the $95 \%$ confidence interval for the estimated average annual element deposition rates $\left(\mathrm{kg} \cdot \mathrm{km}^{-2} \cdot \mathrm{y}^{-1}\right)$ based on lichen bioaccumulation data. 
Table 3. Ranges (95\% confidence intervals) of estimated average annual element deposition rates $\left(\mathrm{kg} \cdot \mathrm{km}^{-2} \cdot \mathrm{y}^{-1}\right)$.

\begin{tabular}{ccc}
\hline Element & Min & Max \\
\hline $\mathrm{Al}$ & 328 & 401 \\
\hline $\mathrm{As}$ & 0.14 & 0.17 \\
\hline $\mathrm{Cd}$ & 0.052 & 0.060 \\
\hline $\mathrm{Ce}$ & 0.69 & 0.81 \\
\hline $\mathrm{Cr}$ & 1.1 & 1.2 \\
\hline $\mathrm{Cu}$ & 5.7 & 7.1 \\
\hline $\mathrm{Fe}$ & 293 & 340 \\
\hline $\mathrm{Ni}$ & 1.4 & 2.1 \\
\hline $\mathrm{Pb}$ & 1.4 & 1.6 \\
\hline $\mathrm{S}$ & 418 & 471 \\
\hline $\mathrm{Sb}$ & 0.15 & 0.25 \\
\hline $\mathrm{Zn}$ & 20.8 & 25.1 \\
\hline
\end{tabular}

\section{Discussion}

Lichens can profitably be used for assessing environmental levels of trace elements, since there is convincing evidence that element bioaccumulation is mainly dependent on environmental availability [9]. The method suggested by Contardo et al. [6] to identify those elements bioaccumulated in lichen transplants allowed to trace $\mathrm{Cu}$ and $\mathrm{Sb}$ as the major contributors to the atmospheric burden in the study area (Montecatini Terme). Copper was accumulated in lichen transplants in $76 \%$ of the sampling sites, with values in the range 1-1.8, indicating a low bioaccumulation. According to the threshold value for the background concentrations (effect detection limit-EDL), antimony was accumulated at all sites, with $43 \%$ of values indicating a high or very high accumulation according to the scale of Cecconi et al. [10]. These results clearly pinpoint $\mathrm{Sb}$ as the main contaminant in the study area. Compared with anthropogenic sources, the contribution of natural sources to the atmospheric burden of $\mathrm{Sb}$ is regarded as negligible [20], and $\mathrm{Sb}$, a common element in vehicle breaks, is now widely used as tracer of vehicle traffic in place of $\mathrm{Pb}$, traditionally linked to motor combustion processes, after the introduction of unleaded fuel [21]. In fact, also in the study area, a relevant decrease of Pb pollution between 1993 and 2000 was observed in native lichens (Flavoparmelia caperata), thanks to the ban of leaded gasoline [22]. In our case, concentrations of $\mathrm{Cu}$ and $\mathrm{Sb}$ were highly correlated $(\mathrm{R}=0.79, p<0.05)$, suggesting a common origin in the study area for these two elements from non-exhaust sources of vehicular traffic, such as brake abrasion [23,24]. In roadsides of Western Europe, Cu emissions from brake wear may be the main source of this metal, accounting for up to $75 \%$ of total $\mathrm{Cu}$ emissions [25]. These results support previous evidence of the ability of lichens to accumulate $\mathrm{Cu}$ and $\mathrm{Sb}$ in urban areas as a result of vehicular traffic [9,26,27], even when exposed within car cabins [28].

Urban airborne particulate matter is known to be enriched in several metals, especially $\mathrm{Cu}$ and $\mathrm{Sb}$, which are mostly apportioned to the fine fraction from 1.1 to $4.7 \mu \mathrm{m}$ [29]. Vehicular traffic is the main source of particulate matter in most European cities [30], and non-exhaust emissions can account for up to $90 \%$ of the released $\mathrm{PM}_{10}$ [31,32]. Emission of particles from vehicle exhausts has now greatly reduced in Europe due to improved control systems, but particles originating from the wearing of brakes and tires, as well as from the resuspension of particles from the road surface, are not decreasing [33]. In addition, it is known that the low emission height of contaminants originating from vehicle traffic is relevant for human health, as contaminants are readily available and concentrated at ground level [34]. 
Urban forestry and urban greening are well known barriers against air pollution [35], since urban trees can consistently reduce PM pollution levels owing to leaf surface adsorption as a consequence of dry deposition processes [36]. Consistently, our results reflected the lowest contamination in proximity of the main urban forested park of the town, further confirming that urban forests provide ecosystem services that contribute to ameliorate not only human well-being but also air quality.

Ranges of estimated mean annual element deposition rates in the study area are consistent with the few data available for nearby sites of Central Italy [37,38], thus confirming the validity of this calculation approach. Calculated fluxes are in line with those reported for urban or even rural areas of Europe [39]; fluxes somewhat higher for $\mathrm{Sb}$ are, however, similar or lower than those reported for several European cities [40].

The availability of a simple biological tool to estimate fluxes of element deposition is of invaluable importance, since it is known that exposure to ambient PM is associated with adverse health effects [41]. In addition, in consideration of the increasing diffusion of urban horticulture, knowledge of element deposition fluxes is very important for the evaluation of potential impacts on such agricultural products and the related consequences for human health through the food chain, since it is known that exposure to ambient PM is associated with adverse health effects [4]. However, it has to be stressed that this study showed evidence limited to trace elements only, without any information about the possible local impact of other important persistent air pollutants, such as polycyclic aromatic hydrocarbons (PAHs), or toxic gaseous air pollutants, such as nitrogen oxides $\left(\mathrm{NO}_{\mathrm{x}}\right)$.

\section{Conclusions}

In this study, we investigated the bioaccumulation of selected trace elements in lichen samples transplanted for three months in the urban area of Montecatini Terme (Central Italy) with the aim of assessing the main environmental contaminants and their sources as well as fluxes of element deposition. The results pinpointed $\mathrm{Cu}$ and $\mathrm{Sb}$ as the main contaminants in the study area and suggested a common origin for these two elements from non-exhaust sources of vehicular traffic, such as brake abrasion. Most study sites were, however, found to be subjected to low or moderate environmental contamination, and the lowest contamination was found in the area of the main urban park, confirming the important protective role of urban forests against air pollution. Ranges of estimated mean annual element deposition rates in the study area were similar or lower than those reported for other urban areas.

Author Contributions: Conceptualization, S.L.; Data curation, L.P.; Formal analysis, S.L.; Funding acquisition, S.L. and A.C.; Investigation, S.L. and L.P.; Methodology, S.L.; Project administration, S.L.; Supervision, S.L.; Writing-original draft, S.L.; Writing—review \& editing, S.L. and L.P.

Funding: The research is based on a monitoring study supported by the Municipality of Montecatini Terme.

Conflicts of Interest: The authors declare no conflict of interest.

\section{References}

1. United Nations. The World's Cities in 2016. Available online: https://www.un.org/en/development/ desa/population/publications/pdf/urbanization/the_worlds_cities_in_2016_data_booklet.pdf (accessed on 23 July 2019).

2. World Health Organization. Ambient (Outdoor) Air Quality and Health. Fact Sheet No 313; World Health Organization: Geneva, Switzerland, 2016. Available online: http://www.who.int/mediacentre/factsheets/ fs313/en/ (accessed on 8 April 2019).

3. Cherin, N.; Roustan, Y.; Musson-Genon, L.; Seigneur, C. Modelling atmospheric dry deposition in urban areas using an urban canopy approach. Geosci. Model. Dev. 2015, 8, 893-910. [CrossRef]

4. Säumel, I.; Kotsyuk, I.; Hölscher, M.; Lenkereit, C.; Weber, F.; Kowarik, I. How healthy is urban horticulture in high traffic areas? Trace metal concentrations in vegetable crops from plantings within inner city neighbourhoods in Berlin, Germany. Environ. Pollut. 2012, 165, 124-132. [CrossRef] [PubMed] 
5. Loppi, S. Lichens as sentinels for air pollution at remote alpine areas (Italy). Environ. Sci. Pollut. Res. 2014, 21, 2563-2571. [CrossRef] [PubMed]

6. Contardo, T.; Giordani, P.; Paoli, L.; Vannini, A.; Loppi, S. May lichen biomonitoring of air pollution be used for environmental justice assessment? A case study from an area of $\mathrm{N}$ Italy with a municipal solid waste incinerator. Environ. Forensics 2018, 19, 265-276. [CrossRef]

7. Loppi, S.; Ravera, S.; Paoli, L. Coping with uncertainty in the assessment of atmospheric pollution with lichen transplants. Environ. Forensics 2019. [CrossRef]

8. Bačkor, M.; Loppi, S. Interactions of lichens with heavy metals. Biol. Plant. 2009, 53, 214-222. [CrossRef]

9. Loppi, S.; Paoli, L. Comparison of the trace element content in transplants of the lichen Evernia prunastri and in bulk atmospheric deposition: A case study from a low polluted environment (C Italy). Biologia 2015, 70, 460-466. [CrossRef]

10. Cecconi, E.; Fortuna, L.; Benesperi, R.; Bianchi, E.; Brunialti, G.; Contardo, T.; Di Nuzzo, L.; Frati, L.; Monaci, F.; Munzi, S.; et al. New interpretative scales for lichen bioaccumulation data: The Italian proposal. Atmosphere 2019, 10, 136. [CrossRef]

11. Paoli, L.; Winkler, A.; Guttová, A.; Sagnotti, L.; Grassi, A.; Lackovičová, A.; Senko, D.; Loppi, S. Magnetic properties and element concentrations in lichens exposed to airborne pollutants released during cement production. Environ. Sci. Pollut. Res. 2017, 24, 12063-12080. [CrossRef]

12. Fernandez, J.A.; Aboal, J.R.; Couto, J.A.; Carballeira, A. Sampling optimization at the sampling-site scale for monitoring atmospheric deposition using moss chemistry. Atmos. Environ. 2002, 36, 1163-1172. [CrossRef]

13. Klumpp, A.; Ansel, W.; Klumpp, G.; Breuer, J.; Vergne, P.; Sanz, M.J.; Rasmussen, S.; Ro-Poulsen, H.; Ribas, A.; Penuelas, J.; et al. Airborne trace element pollution in 11 European cities assessed by exposure of standardised ryegrass cultures. Atmos. Environ. 2009, 43, 329-339. [CrossRef]

14. Couto, J.A.; Aboal, J.R.; Fernandez, J.A.; Carballeira, A. A new method for testing the sensitivity of active biomonitoring: An example of its application to a terrestrial moss. Chemosphere 2004, 57, 303-308. [CrossRef] [PubMed]

15. Frati, L.; Brunialti, G.; Loppi, S. Problems related to lichen transplants to monitor trace element deposition in repeated surveys: A case study from central Italy. J. Atmos. Chem. 2005, 52, 221-230. [CrossRef]

16. Loppi, S.; Pirintsos, S.A.; De Dominicis, V. Soil contribution to the elemental composition of epiphytic lichens (Tuscany, Central Italy). Environ. Monit. Assess. 1999, 58, 121-131. [CrossRef]

17. Bini, C.; Dall'Aglio, M.; Ferretti, O.; Gragnani, R. Background levels of microelements in soils of Italy. Environ. Geochem. Health 1988, 10, 63-69. [CrossRef] [PubMed]

18. Nannoni, F.; Protano, G. Chemical and biological methods to evaluate the availability of heavy metals in soils of the Siena urban area (Italy). Sci. Total Environ. 2016, 568, 1-10. [CrossRef] [PubMed]

19. Loppi, S.; Pirintsos, S.A. Epiphytic lichens as sentinels for heavy metal pollution at forest ecosystems (central Italy). Environ. Pollut. 2003, 121, 327-332. [CrossRef]

20. Nriagu, J.O. A history of global metal pollution. Science 1996, 272, 223. [CrossRef]

21. Varrica, D.; Bardelli, F.; Dongarra, G.; Tamburo, E. Speciation of Sb in airborne particulate matter, vehicle brake linings, and brake pad wear residues. Atmos. Environ. 2013, 64, 18-24. [CrossRef]

22. Loppi, S.; Frati, L.; Paoli, L.; Bigagli, V.; Rossetti, C.; Bruscoli, C.; Corsini, A. Biodiversity of epiphytic lichens and heavy metal contents of Flavoparmelia caperata thalli as indicators of temporal variations of air pollution in the town of Montecatini Terme (central Italy). Sci. Total Environ. 2004, 326, 113-122. [CrossRef]

23. Wåhlin, P.; Berkowicz, R.; Palmgren, F. Characterisation of traffic-generated particulate matter in Copenhagen. Atmos. Environ. 2006, 40, 2151-2159. [CrossRef]

24. Jeong, C.H.; Wang, J.M.; Hilker, N.; Debosz, J.; Sofowote, U.; Su, Y.; Noble, M.; Munoz, T.; Dabek-Zlotorzynska, E.; Celo, V.; et al. Temporal and spatial variability of traffic-related PM2.5 sources: Comparison of exhaust and non-exhaust emissions. Atmos. Environ. 2019, 198, 55-69. [CrossRef]

25. Van der Gon, H.D.; Hulskotte, J.H.J.; Visschedijk, A.J.H.; Schaap, M. A revised estimate of copper emissions from road transport in UNECE-Europe and its impact on predicted copper concentrations. Atmos. Environ. 2007, 41, 8697-8710. [CrossRef]

26. Paoli, L.; Munzi, S.; Fiorini, E.; Gaggi, C.; Loppi, S. Influence of angular exposure and proximity to vehicular traffic on the diversity of epiphytic lichens and the bioaccumulation of traffic-related elements. Environ. Sci. Pollut. Res. 2013, 20, 250-259. [CrossRef] [PubMed] 
27. Vannini, A.; Paoli, L.; Russo, A.; Loppi, S. Contribution of submicronic (PM1) and coarse (PM> 1) particulate matter deposition to the heavy metal load of lichens transplanted along a busy road. Chemosphere 2019, 231, 121-125. [CrossRef] [PubMed]

28. Paoli, L.; Maccelli, C.; Guarnieri, M.; Vannini, A.; Loppi, S. Lichens "travelling" in smokers' cars are suitable biomonitors of indoor air quality. Ecol. Indic. 2019, 103, 576-580. [CrossRef]

29. Zereini, F.; Alt, F.; Messerschmidt, J.; Wiseman, C.; Feldmann, I.; Von Bohlen, A.; Müller, L.; Liebl, K.; Püttmann, W. Concentration and distribution of heavy metals in urban airborne particulate matter in Frankfurt am Main, Germany. Environ. Sci. Technol. 2005, 39, 2983-2989. [CrossRef]

30. Karagulian, F.; Belis, C.A.; Dora, C.F.C.; Prüss-Ustün, A.M.; Bonjour, S.; Adair-Rohani, H.; Amann, M. Contributions to cities' ambient particulate matter (PM): A systematic review of local source contributions at global level. Atmos. Environ. 2015, 120, 475-483. [CrossRef]

31. Omstedt, G.; Bringfelt, B.; Johansson, C. A model for vehicle-induced non-tailpipe emissions of particles along Swedish roads. Atmos. Environ. 2005, 39, 6088-6097. [CrossRef]

32. Forsberg, B.; Hansson, H.C.; Johansson, C.; Areskoug, H.; Persson, K.; Jarvholm, B. Comparative health impact assessment of local and regional particulate air pollutants in Scandinavia. AMBIO A J. Hum. Environ. 2005, 34, 11-19. [CrossRef]

33. European Environment Agency. Environmental Indicator Report 2018-In Support to the Monitoring of the 7th Environment Action Programme; EEA Report No19/2018. Luxembourg, 2018. Available online: https://www.eea.europa.eu/publications/environmental-indicator-report-2018 (accessed on 8 April 2019).

34. Wu, Y.; Hao, J.; Fu, L.; Wang, Z.; Tang, U. Vertical and horizontal profiles of airborne particulate matter near major roads in Macao, China. Atmos. Environ. 2002, 36, 4907-4918. [CrossRef]

35. Baraldi, R.; Chieco, C.; Neri, L.; Facini, O.; Rapparini, F.; Morrone, L.; Rotondi, A.; Carriero, G. An integrated study on air mitigation potential of urban vegetation: From a multi-trait approach to modeling. Urban For. Urban Green. 2019, 41, 127-138. [CrossRef]

36. Manes, F.; Marando, F.; Capotorti, G.; Blasi, C.; Salvatori, E.; Fusaro, L.; Ciancarella, L.; Mircea, M.; Marchetti, M.; Chirici, G.; et al. Regulating ecosystem services of forests in ten Italian metropolitan cities: Air quality improvement of $\mathrm{PM}_{10}$ and $\mathrm{O}_{3}$ removal. Ecol. Indic. 2016, 67, 425-440. [CrossRef]

37. ARPAT. Regional Agency for Environmental Protection in Tuscany] Campagna di caratterizzazione deposizioni umide e secche 2011-2013, Postazione Badia al Pino, Comune Civitella in Val di Chiana, Arezzo. Regione Toscana 2016a. Available online: http://www.arpat.toscana.it/documentazione/report/ civitella-val-di-chiana-ar-campagna-di-caratterizzazione-delle-deposizioni-umide-e-secche (accessed on 8 April 2019).

38. ARPAT. Regional Agency for Environmental Protection in Tuscany]Campagna di caratterizzazione deposizioni umide e scche 2011-2013, postazione Castelluccio, Comune Capolona-Arezzo. Regione Toscana 2016b. Available online: http://www.arpat.toscana.it/documentazione/catalogo-pubblicazioni-arpat/ approfondimenti-aria/capolona-ar-campagna-di-caratterizzazione-delle-deposizioni-umide-e-secche (accessed on 8 April 2019).

39. European Commission. Ambient Air Pollution by As, Cd and Ni Compounds; Position Paper. European Commission DG Environment, 2001. Available online: http://ec.europa.eu/environment/archives/air/pdf/pp_ as_cd_ni.pdf (accessed on 8 April 2019).

40. Langner, M.; Kull, M.; Endlicher, W.R. Determinaton of $\mathrm{PM}_{10}$ deposition based on antimony flux to selected urban surfaces. Environ. Pollut. 2011, 159, 2028-2034. [CrossRef] [PubMed]

41. Churg, A.; Brauer, M.; del Carmen Avila-Casado, M.; Fortoul, T.I.; Wright, J.L. Chronic exposure to high levels of particulate air pollution and small airway remodeling. Environ. Health Perspect. 2003, 111, 714-718. [CrossRef] [PubMed]

(C) 2019 by the authors. Licensee MDPI, Basel, Switzerland. This article is an open access article distributed under the terms and conditions of the Creative Commons Attribution (CC BY) license (http://creativecommons.org/licenses/by/4.0/). 